\title{
A RETROSPECTIVE STUDY ON PATTERN OF THALASSEMIA AND OTHER HAEMOGLOBINOPATHIES IN PAEDIATRICS AGE GROUP USING HIGH PERFORMANCE LIQUID CHROMATOGRAPHY IN JORHAT DISTRICT OF NORTH EAST INDIA
}

\author{
Dipangkar Hazarika¹, Ananta Kumar Nath², Pranabjit Biswanath³, Ankur Borah4, Jayanta Patir 5 \\ ${ }^{1}$ Assistant Professor, Department of Paediatrics. Jorhat Medical College and Hospital, Jorhat, Assam. \\ ${ }^{2}$ Registrar, Department of Paediatrics, Jorhat Medical College and Hospital, Jorhat, Assam. \\ 3 Professor and HOD, Department of Paediatrics, Jorhat Medical College and Hospital, Jorhat, Assam. \\ ${ }^{4}$ Consultant Pathologist, Department of Haematology, Jyoti Pathology Laboratory, Jorhat, Assam. \\ ${ }_{5}^{5}$ Consultant Pathologist, Department of Haematology, Prime Pathology Laboratory, Jorhat, Assam.
}

\section{ABSTRACT}

\section{BACKGROUND}

In India, haemoglobinopathies and thalassemias contribute in a significant number of paediatric cases with anaemia. As corrective treatment like bone marrow transplantation is costly, prevention through population screening, and genetic counselling is the best possible strategy.

\section{AIMS}

Data pertaining to the pattern of these disorders is scarce in this region and hence it was considered worthwhile to study these disorders using a large series of patients referred to clinical diagnostic laboratory.

\section{METHOD}

A retrospective study was done on 800 patients who were referred for $\mathrm{Hb}$ variant analysis to two clinical diagnostic laboratories in Jorhat District in upper Assam region of North East India between the age group of 7 months to 18 years. This study was performed by high performance liquid chromatography (HPLC) using BIORAD (D-10) variant Hb typing system.

\section{RESULT}

Out of 800 patients, abnormal $\mathrm{Hb}$ fractions were seen in 417 (51.9\%) patients. HbE gene was detected in 373 patients of which $\mathrm{HbE}$ trait was seen in 243 (58.7\%) followed by HbE disease in 100 (23.9\%). There were 30 (7.19\%) HbE beta thalassemia cases. Out of 46 tea garden community cases, 41 showed $\mathrm{HbS}$ gene of which 12 (2.87\%) each in $\mathrm{HbS}$ trait and $\mathrm{HbS}$ thalassemia groups and 17 patients in sickle cell anaemia group (4.07\%). HbE thalassemia was mainly found in Chutia (1.92\%), Ahom (1.43\%) and Mishing $(1.67 \%)$ communities.

\section{CONCLUSION}

A high incidence of haemoglobinopathies and thalassemias and their combinations is unique for this part of the country particularly the high prevalence of $\mathrm{HbE}$ thalassemia. $\mathrm{HbS}$ gene is mainly found in tea garden community.

\section{KEYWORDS}

Haemoglobinopathies, Thalassemia, High Performance Liquid Chromatography, Paediatrics, North Eastern India.

HOW TO CITE THIS ARTICLE: Hazarika D, Nath AK, Biswanath P, et al. A retrospective study on pattern of thalassemia and other haemoglobinopathies in paediatrics age group using high performance liquid chromatography in Jorhat district of north east India. J. Evolution Med. Dent. Sci. 2016;5(56):3818-3822, DOI: 10.14260/jemds/2016/874

\section{INTRODUCTION}

Thalassemia and other haemoglobinopathies are a group of hereditary disorders of haemoglobin $(\mathrm{Hb})$ where there is quantitative and qualitative abnormal production or structure of $\mathrm{Hb}$ molecule, 1,2 a major public health problem in many parts of India. ${ }^{2}$

There are over 25 million carriers of this disease in India ${ }^{3}$ and beta thalassemia and sickle cell disease are the most frequent among them. ${ }^{2.4}$ The clinical presentation may vary

Financial or Other, Competing Interest: None.

Submission 07-06-2016, Peer Review 02-07-2016,

Acceptance 07-07-2016, Published 12-07-2016.

Corresponding Author:

Dr. Dipangkar Hazarika,

Assistant Professor,

Department of Paediatrics,

Jorhat Medical College and Hospital,

Jail Road, Jorhat-785001, Assam, India.

E-mail: dipankargmch@gmail.com

DOI: $10.14260 /$ jemds $/ 2016 / 874$ from asymptomatic carrier state to more serious condition like thalassemia major, which requires regular blood transfusion ${ }^{2}$ and yearly 10,000 children are born with beta thalassemia major in India, which contributes to $10 \%$ of the total number of thalassemia major in the world. 5 Indian Council of Medical Research (ICMR) in their multicenter study have found the incidence of beta thalassemia to be $2.78 \%{ }^{6}$ The prevalence of sickle cell anaemia and beta thalassemia trait in India varies between $1-44 \%$ and $3-17 \%$ and respectively. 1,2

In different parts of India, the incidence of haemoglobinopathies also differs. In Orissa, $\mathrm{HbS}$ is common ${ }^{7}$ whereas in West Bengal the commonest one is HbE. ${ }^{8}$ ICMR multicenter study showed that $\mathrm{HbE}$ trait was mainly seen in Kolkata in West Bengal (3.92\%) and in Dibrugarh in Assam (23.9\%). Among the six ethnic groups from Dibrugarh Assam, the prevalence of $\mathrm{HbE}$ trait varied from $41.1 \%$ to $66.7 \% .^{6}$ The incidence of $\mathrm{HbE}$ gene in the North Eastern region of India is one of the highest in the world. ${ }^{9} \mathrm{~A}$ huge migrant tea garden 
population also shows a high incidence of $\mathrm{HbS}$ in North East India. ${ }^{10,11}$

The curative treatment is costly and these children require frequent blood transfusion. The best preventive measure is through population screening and genetic counselling. ${ }^{12}$

As the exact data regarding the pattern of thalassemia and other haemoglobinopathies in paediatrics age group of different ethnic groups in this region is limited as majority studies were adult case based. We consider it important to find out the extent of burden of these conditions in anaemic children of various age group, sex, and community.

\section{MATERIAL AND METHOD}

A retrospective study was done in paediatrics population between the age group of 7 months to 18 years. As the prevalence of thalassemia varies with different geographical areas of India. $1,2,7,8$ we took the prevalence of $66.7 \%$ among the six ethnic groups from Assam ${ }^{6}$ while calculating the sample size. Taking relative error of $5 \%$ of prevalence, the sample size calculated was 800 cases. Paediatrics patients who were referred for $\mathrm{Hb}$ variant analysis to two clinical laboratories by clinicians as a workup for anaemia and for confirmation of clinically suspected patients of haemoglobinopathy or thalassemia in Jorhat district in upper Assam region of North East India were included in the study. The patient predominantly belongs to people of upper Assam, which is considered a mosaic of people with diverse ethnicity and cultural identity. ${ }^{11}$

The study was done between April 2013 and January 2016. $2 \mathrm{ml}$ EDTA blood samples were collected by venepuncture from each subject. All these samples were analysed for haemoglobin disorders by using High Performance Liquid Chromatography (HPLC) based upon the principles of cation exchange chromatography using the Bio-Rad (D-10) variant $\mathrm{Hb}$ typing system. Though HPLC helps in the establishment of diagnosis in such cases the ultimate diagnosis is made by identification of abnormal gene using polymerase chain reaction. ${ }^{13}$

Details of subjects were recorded in a proforma, which included age, sex, caste/ethnic groups, and pattern of $\mathrm{Hb}$ fraction on HPLC. Major communities/ethnic groups of the region were included. Those groups where the community/ethnic groups were not mentioned were pooled together under the 'others' group. Data was compiled in excel sheet and statistical analysis was done with appropriate statistical methods.

\section{RESULTS}

Out of 800 cases, 417 (51.9\%) displayed abnormal haemoglobin fractions on HPLC. The major abnormality observed in thalassemia cases was high $\mathrm{HbA} 2$. A cutoff over $3.9 \%$ was taken for diagnosis of beta thalassemia trait. 14

Table 1 shows the sex distribution, out of 417 cases 230 (55.15\%) were male and 187 (44.84\%) were female and the difference was found to be statistically significant.

Table 2 shows the pattern of various haemoglobinopathies and thalassemia in our study. Out of 417 cases 243 cases showed HbE trait (58.2\%) followed by HbE disease (23.9\%), E. thalassemia (7.19\%), Sickle cell anaemia (4.07\%), S. trait $(2.87 \%)$, S. thalassemia $(2.87 \%)$, beta thalassemia and beta thalassemia trait $(0.23 \%)$.
Table 3 shows the age distribution of cases. Out of 417 cases, $32.4 \%$ cases were of 10-18 years age group followed by 1-3 yeas (19.4\%), 4-6 years (19.2\%), and 7-10 years $(18.5 \%)$, and between 7-12 months, it was (10.6\%). Table 3 also shows the pattern of haemoglobinopathies and thalassemia in different age group. $\mathrm{HbE}$ trait (18.22\%), HbE disease (7.67\%), S. trait (1.67\%), and S. thalassemia were most common in 1018 years age group. Most of the cases of E. thalassemia (2.39\%) were found in 7-12 months age group. Sickle cell anaemia was commonly seen in 1-3 years and 10-18 years age group. One case each of beta thalassemia was noted in 7-12 months and 710 years age group. Age-wise distribution of cases found to be statistically significant.

Table 4 shows the distribution of haemoglobinopathies and thalassemia in different community/ethnic groups. In the present study, HbE trait (58.27\%) was the most common type of haemoglobinopathy. Second most common pattern noted was $\mathrm{HbE}$ homozygous ( $\mathrm{HbE}$ disease) with 23.9\%. Among different haemoglobinopathies $\mathrm{HbE}$ trait, $\mathrm{HbE}$ disease, and $\mathrm{HbE}$ thalassemia showed significant statistical difference among different communities.

The most significant finding of our study was the high incidence of $\mathrm{HbE}$ beta thalassemia (7.19\%). The $\mathrm{HbS}$ gene was detected in $9.81 \%$ of patients of which sickle cell anaemia was the predominant form (4.07\%) followed by HbS trait (2.87\%) and S. beta thalassemia (2.87\%). Children with sickle cell anaemia showed high level of foetal $\mathrm{Hb}$ level, which ranges between $12.2 \%$ and $24.4 \%$.

Among the ethnic groups, $\mathrm{HbE}$ trait is most common among Ahom (13.66\%), Chutia (15.5\%), and Mishing (6.23\%) communities. HbE disease was mainly found in Ahom (6.47\%) and Chutia (5.9\%) communities. HbE thalassemia was mainly found in Chutia (1.92\%), Ahom (1.43\%), and Mishing (1.67\%) communities.

In our study, $\mathrm{HbS}$ was mainly restricted to tea garden community. Total 46 patients from tea garden community were included in this study out of which 17 (36.95\%) cases were found to have sickle cell anaemia and 12 (26\%) cases each in $\mathrm{HbS}$ trait and $\mathrm{S}$. thalassemia groups. Two patients found to have B thalassemia major and beta thalassemia trait in one patient.

\begin{tabular}{|c|c|c|}
\hline Sex & Male & Female \\
\hline No. of cases & $230(55.15 \%)$ & $187(44.84 \%)$ \\
\hline \multicolumn{2}{|c|}{$\mathcal{x}^{2}=4.434 ; \mathrm{df}=1 ; \mathrm{P}$ value $=0.0352$} \\
\hline \multicolumn{2}{|c|}{ Table 1: Sex Distribution of } \\
Haemoglobinopathies and Thalassemia $(\mathbf{n = 4 1 7})$ \\
\hline
\end{tabular}

$\mathrm{df}=$ degree of freedom

\begin{tabular}{|c|c|c|}
\hline Variant Hb & No. & Percentage \\
\hline HbE Trait & 243 & $58.27 \%$ \\
HbE Disease & 100 & $23.9 \%$ \\
E Thalassemia & 30 & $7.19 \%$ \\
B Thalassemia & 2 & $0.47 \%$ \\
B Thalassemia Trait & 1 & $0.23 \%$ \\
S Trait & 12 & $2.87 \%$ \\
S Thalassemia & 12 & $2.87 \%$ \\
Sickle Cell Anaemia & 17 & $4.07 \%$ \\
\hline \multicolumn{2}{|c|}{ Table 2: Type Wise Distribution of Various } \\
Haemoglobinopathies and Thalassemia (n=417) \\
\hline
\end{tabular}




\begin{tabular}{|c|c|c|c|c|c|c|c|c|c|}
\hline $\begin{array}{l}\text { Age } \\
\text { Group }\end{array}$ & $\begin{array}{l}\mathrm{Hb} E \\
\text { Trait }\end{array}$ & $\begin{array}{c}\text { Hb E } \\
\text { Disease }\end{array}$ & $\begin{array}{c}\text { E } \\
\text { Thalassemia }\end{array}$ & $\begin{array}{c}\text { B } \\
\text { Thalassemia }\end{array}$ & $\begin{array}{c}S \\
\text { Trait }\end{array}$ & $\begin{array}{c}\text { S } \\
\text { Thalassemia }\end{array}$ & $\begin{array}{l}\text { Sickle Cell } \\
\text { Anaemia }\end{array}$ & \begin{tabular}{|c|} 
Beta \\
Thalassemia \\
Trait \\
\end{tabular} & $\begin{array}{c}\text { Cases } \\
\%\end{array}$ \\
\hline $7-12 \mathrm{M}$ & $26(6.23 \%)$ & $5(1.2 \%)$ & $10(2.39 \%)$ & $1(0.23 \%)$ & $1(0.23 \%)$ & & & $1(0.23 \%)$ & $44(10.6 \%)$ \\
\hline 1 yrs.-3 yrs. & $43(10.31 \%)$ & $23(5.51 \%)$ & $8(1.91 \%)$ & & $1(0.23 \%)$ & & $6(1.43 \%)$ & & $81(19.4 \%)$ \\
\hline $4-6$ yrs. & $52(12.47 \%)$ & $20(4.79 \%)$ & $2(0.47 \%)$ & & $1(0.23 \%)$ & $3(0.71 \%)$ & $2(0.47 \%)$ & & $80(19.2 \%)$ \\
\hline $7-10$ yrs. & $46(11.03 \%)$ & $20(4.79 \%)$ & $4(0.95 \%)$ & $1(0.23 \%)$ & $2(0.47 \%)$ & $1(0.23 \%)$ & $3(0.71 \%)$ & & 77 (18.5\%) \\
\hline 10-18 yrs. & $76(18.22 \%)$ & $32(7.67 \%)$ & $6(1.43 \%)$ & & $7(1.67 \%)$ & $8(1.91 \%)$ & $6(1.43 \%)$ & & $135(32.4 \%)$ \\
\hline Total & $243(58.27 \%)$ & $100(23.9 \%)$ & $30(7.19 \%)$ & $2(0.47 \%)$ & $12(2.87 \%)$ & $12(2.87 \%)$ & $17(4.07 \%)$ & $1(0.23 \%)$ & 417 \\
\hline \multicolumn{10}{|c|}{$\mathcal{X}^{2}=56.1 ; \mathrm{df}=32 ; \mathrm{P}$ value $=0.005$} \\
\hline
\end{tabular}

\begin{tabular}{|c|c|c|c|c|c|c|c|c|c|}
\hline $\begin{array}{c}\text { Community/ } \\
\text { Ethnic } \\
\text { Groups }\end{array}$ & HbE Trait & $\begin{array}{c}\text { HbE } \\
\text { Disease }\end{array}$ & E Thala & $\begin{array}{l}\text { Beta } \\
\text { Thala } \\
\text { Major }\end{array}$ & $\begin{array}{l}\text { Beta } \\
\text { Thala } \\
\text { Trait }\end{array}$ & $S$ Trait & $\begin{array}{c}\text { Sickle Cell } \\
\text { Anaemia }\end{array}$ & $\begin{array}{c}S \\
\text { Thalassemia }\end{array}$ & Cases \% \\
\hline Brahmin & $9(2.15 \%)$ & $4(0.95 \%)$ & & & & & & & $13(3.1 \%)$ \\
\hline Kalita & $8(1.91 \%)$ & & & & & & & & $8(1.91 \%)$ \\
\hline Koch & $7(1.67 \%)$ & $4(0.95 \%)$ & & & & & & & $11(2.63 \%)$ \\
\hline Keot & $2(0.47 \%)$ & & & & & & & & $2(0.47 \%)$ \\
\hline Muttok & $1(0.23 \%)$ & $1(0.23 \%)$ & & & & & & & $2(0.47 \%)$ \\
\hline Sunni & $10(2.4 \%)$ & $1(0.23 \%)$ & $1(0.23 \%)$ & & & & & & $12(2.87 \%)$ \\
\hline Ahom & $57(13.66 \%)$ & 27 (6.47\%) & $6(1.43 \%)$ & & & & & & $90(21.58 \%$ \\
\hline Chutia & $65(15.5 \%)$ & $25(5.9 \%)$ & $8(1.92 \%)$ & & $1(0.23 \%)$ & & & & $99(23.74 \%$ \\
\hline Shut & $1(0.23 \%)$ & $1(0.23 \%)$ & & & & & & & $2(0.47 \%)$ \\
\hline Mech & $3(0.71 \%)$ & $2(0.47 \%)$ & & & & & & & $5(1.19 \%)$ \\
\hline Kaibarta & $19(4.55 \%)$ & $2(0.47 \%)$ & $2(0.47 \%)$ & $1(0.23 \%)$ & & & & & $24(5.75 \%)$ \\
\hline Bodo & $1(0.23 \%)$ & & & & & & & & $1(0.23 \%)$ \\
\hline Kachari & $14(3.35 \%)$ & $13(3.11 \%)$ & $3(0.71 \%)$ & & & & & & $30(7.19 \%)$ \\
\hline Deori & $3(0.71 \%)$ & $1(0.23 \%)$ & $1(0.23 \%)$ & & & & & & $5(1.19 \%)$ \\
\hline Mishing & $26(6.235)$ & $15(3.6 \%)$ & $7(1.67 \%)$ & & & & & & $48(11.5 \%)$ \\
\hline $\begin{array}{l}\text { Tea Garden } \\
\text { Community }\end{array}$ & $2(0.47 \%)$ & & $2(0.47 \%)$ & $1(0.23 \%)$ & & $12(2.87 \%)$ & 17 (4.07\%) & $12(2.87 \%)$ & $46(11.0 \%)$ \\
\hline other & $15(3.59 \%)$ & $4(0.95 \%)$ & & & & & & & $19(4.55 \%)$ \\
\hline Total & $\begin{array}{c}243 \\
(58.27 \%)\end{array}$ & $\begin{array}{c}100 \\
(23.9 \%)\end{array}$ & $\begin{array}{c}30 \\
(7.19 \%)\end{array}$ & $\begin{array}{c}2 \\
(0.47 \%)\end{array}$ & $\begin{array}{c}1 \\
(0.23 \%)\end{array}$ & $\begin{array}{c}12 \\
(2.87 \%)\end{array}$ & $\begin{array}{c}17 \\
(4.07 \%)\end{array}$ & $\begin{array}{c}12 \\
(2.87 \%)\end{array}$ & 417 \\
\hline t test & 3.1004 & 2.7778 & 2.7133 & 1.4606 & 1.0000 & 1.0852 & 1.0609 & 1.0852 & 3.3607 \\
\hline $\mathrm{p}$ value & 0.0069 & 0.0134 & 0.0153 & 0.1635 & 0.3332 & 0.2939 & 0.3045 & 0.2939 & 0.004 \\
\hline \multicolumn{10}{|c|}{ Table 4: Community/Ethnic Group Wise Distribution of Haemoglobinopathies and Thalassemia (n=417) } \\
\hline
\end{tabular}

\section{DISCUSSION}

Thalassemia and other haemoglobinopathies are autosomal recessive disorders, which are mainly confined to certain areas, religions, cast, and tribes predominantly because of migration of population from one place to another and marriage between different communities. 15

The results of present study were compared with those of other studies. Majority studies were adult-case based. There are limited studies, which were done on paediatrics population.

Maximum numbers of cases were between 10-18 years (32.4\%) followed by 1-3 years (19.4\%), 4-6 years (19.2\%), 710 years $(18.5 \%)$, and between $7-12$ months, it was $(10.6 \%)$. Shah SJ et al. found $34.3 \%$ cases in 10 or more years of age group followed by $31.4 \%$ cases between $1-3$ years of age. 16

Regarding the sex distribution, out of 417 cases 230 (55.15\%) were male and 187 (44.84\%) were female. Shah SJ et al. found male predominance with $74.3 \%$ and male to female ratio being approximately 3:1.16 Coelho $\mathrm{G}$ et al. found $70.6 \%$ males and $29.4 \%$ females in their study. ${ }^{17}$ Karthika $M$ et al. found male predominance in their study $(56.86 \%$ vs $43.13 \%) .{ }^{18}$
In the present study, $\mathrm{HbE}$ trait $(58.27 \%)$ was the most common type of haemoglobinopathy. In ICMR multi-centre study, which included Kolkata in West Bengal in the east, Dibrugarh in Assam in the North East India among six cities showed a prevalence of $\mathrm{HbE}$ trait as $3.92 \%$ in Kolkata and $23.9 \%$ in Dibrugarh. In six ethnic groups from Assam, the prevalence of $\mathrm{HbE}$ trait varied from $41.1 \%$ to $66.7 \% .^{6}$ Earlier studies on $\mathrm{HbE}$ have shown that the prevalence is very variable with some population groups like the Mizos from Mizoram in the north east having the prevalence of $\mathrm{HbE}$ trait of $1.5 \%{ }^{19}$ while among different tribal groups in Tripura and among the Mishings of upper Assam and Phayengs and Khurkhvels of Manipur the prevalence of $\mathrm{HbE}$ trait ranged from $16.2 \%$ to $47.3 \% .20,21,22$ The Bodo-Kacharis were shown earlier to have one of the highest reported prevalence of $\mathrm{HbE}$ trait (64\%). ${ }^{9}$ These findings were similar to our study.

Second most common pattern noted was $\mathrm{HbE}$ homozygous (HbE disease) with 23.9\%. Baruah MK et al. reported similar findings with $21.07 \%$ of patients had $\mathrm{HbE}$ disease in a study done in upper Assam, India. ${ }^{23}$ Aggarwal S et al. reported an incidence of $16.6 \%$ of $\mathrm{HbE}$ disease. ${ }^{24}$ Chattopadhyay $\mathrm{K}$ et al. reported a prevalence of $7.4 \%$ of $\mathrm{HbE}$ disease. ${ }^{25}$ 
The most significant finding of our study was the high incidence of $\mathrm{HbE}$ beta thalassemia (7.19\%). Most of the studies from the region showed low incidence of $\mathrm{Hb}$ E-beta thalassemia. Baruah MK et al reported a low incidence of $\mathrm{HbE}$ thalassemia (1.2\%).23 ICMR study reported a incidence of $1.44 \%$ in general population. 6 This finding is important as early report from North East India reported only seven cases. ${ }^{26}$ The high incidence in our study could be because of few factors, first one was more interaction and marriage between different ethnic groups in this region as migration of various communities overtime, second it was a laboratory-based study as opposed to a population-based study and we analysed those referred children who were anaemic.

The HbS gene was detected in $9.81 \%$ of patients, of which sickle cell anaemia was the predominant form $(4.07 \%)$ followed by $\mathrm{HbS}$ trait $(2.87 \%$ and S beta thalassemia (2.87\%). Baruah MK et al. reported $\mathrm{HbS}$ gene in $5.11 \%$ of patients of which sickle cell anaemia was the predominant form $(2.26 \%)$ followed by $2.10 \%$ for $\mathrm{HbS}$ trait and $0.59 \%$ for S. beta thalassemia. ${ }^{23}$ As it is a laboratory-based study, the high incidence of sickle cell anaemia maybe because of this Children with sickle cell anaemia showed high level of fetal $\mathrm{Hb}$ level. Baruah MK et al. reported similar finding in their study. ${ }^{23}$ This may be due to the prevalent haplotype in India is Saudi Arabia/Indian haplotype. This haplotype is associated with higher levels of $\mathrm{HbF}$, which reduces the clinical severity of the disease. ${ }^{27}$

Among the ethnic groups, $\mathrm{HbE}$ trait is most common among Ahom (13.66\%), Chutia (15.5\%), and Mishing (6.23\%) communities. Earlier studies by ICMR from the region reported that though the $\mathrm{HbE}$ trait had been detected across all ethnic groups in Assam. It was most commonly found in Ahom, Koch, Chutia, Muttock, Deori, and Mishing communities. ${ }^{6}$ In our study, we found few cases in Muttock, Deori, and Koch communities probably because less population of these communities in this region. HbE disease was mainly found in Ahom (6.47\%) and Chutia (5.9\%) communities. HbE thalassemia was mainly found in Chutia (1.92\%), Ahom (1.43\%), and Mishing (1.67\%) communities.

In our study, $\mathrm{HbS}$ gene was mainly restricted to tea garden community. Total 46 patients from tea garden community were included in this study out of which 17 (36.95\%) cases were found to have sickle cell anaemia and $12(26 \%)$ cases each in $\mathrm{HbS}$ trait and S. thalassemia groups. A similar finding was reported by Sharma SK et al. in tea garden community, a group of population brought to Assam by the British colonial tea planters from central, Eastern and Southern India during mid-19 ${ }^{\text {th }}$ century. ${ }^{11}$ The sickle cell anaemia and sickle cell trait are found in relatively high frequency among the endogenous population of India. The highest of $22.2 \%$ has been found in Lohars of Orissa followed by Mahars of Madhya Pradesh (20\%), and Kinkars of Assam (18.3\%). The average sickle cell gene frequency is highest in Orissa (9.1\%) followed by Assam $(8.3 \%) .28$

HPLC helps in the establishment of diagnosis in these types of cases. The confirmatory diagnosis is made by identification of abnormal gene using polymerase chain reaction. ${ }^{13}$ As these facilities are not available in our setup, we could not carry out these tests in our study.

Prevention programmes are important for these conditions. In countries like Cyprus, Italy, and Greece control of thalassemia is achieved through various prevention programmes. In these countries, population education, and screening forms the most important part.29,30,31 In country like India, which carry remarkable diversity in frequency of thalassemia and other haemoglobinopathies accurate micro mapping is important while estimating the disease burden for planning the preventive programmes. ${ }^{32}$

$\mathrm{HbE}$ thalassemia is highly prevalent in this part of NorthEast India along with other $\mathrm{HbE}$ variants. Compared to other studies from this region, we found high prevalence of $\mathrm{HbE}$ thalassemia. HbS gene is mainly found in tea garden community. Because of costly curative treatment like bone marrow transplantation and other medical care, the best way to prevent this condition is through population screening and genetic counselling.

\section{REFERENCES}

1. Patel AP, Naik MR, Shah NM, et al. Prevalence of common haemoglobinopathies in Gujarat. An analysis of a large population screening programme. National Journal of Community Medicine 2012;3(1):112-6.

2. Parikh UR, Goswami HM, Mehta RC, et al. Incidence of haemoglobinopathies in women attending antenatal clinics in their first trimester. NHL Journal of Medical Science 2014;3(1):63-7.

3. Saxena A, Phadke SR. Thalassemia control by carrier screening: the Indian scenario. Current science 2002;83(3):291-5.

4. Ahmed A, Naser A, Hassan TA, et al. Detection of haemoglobinopathies in hypochromic microcytic and sickle cell blood film by haemoglobin electrophoresis. Thi-Qar Medical Journal 2011;5(1):139-48.

5. Varawalla NY, Old JM, Sarkar R, et al. The spectrum of beta thalassemia mutation on the Indian subcontinent: the basis for prenatal diagnosis. Br J Haematal 1991;78 (2): 242-7.

6. Mohanty D, Colah RB, Gorakshakar AC, et al. Prevalence of beta thalassemia and other haemoglobinopathies in six cities in India. A multicentre study. J Community Genet 2013;4(1):33-42.

7. Dolai TK, Dutta S, Bhattacharya $M$, et al. Prevalence of haemoglobinopathies in rural Bengal, India. Haemoglobin 2012;36(1):57-63.

8. Jain BB, Roy RN, Ghosh S, et al. Screening for thalassemia and other haemoglobinopathies in a tertiary care hospital of West Bengal implication for population screening. Indian J Public Health 2012;56(4):297-300.

9. Deka R, Reddy AP, Mukherjee BN, et al. Haemoglobin E. distribution in ten endogenous population groups of Assam, India. Hum Hered 1988;38(5):261-6.

10. Balgir RS. Epidemiology, population health genetics and phenotypic diversity of sickle cell disease in India. Internet J Biol Anthropal 2007;1:2.

11. Sharma SK, Mahanta J. Prevalence of $\mathrm{Hb}$ variants in malaria endemic north east India. J Bio Sci 2009;9:288-91.

12. Bhalodia NJ, Oza VH, Modi JP, et al. Study of haemoglobinopathies in patient of anaemia using high performance liquid chromatography in western India. National Journal Of Community Medicine 2015;6(1): 35-40.

13. Chandra S. Haemoglobin E-beta thalassemia: clinical features. In: Haemoglobinopathies. Sachdeva A, 
Lokeshwar MR, Shah N, et al. (Eds). $1^{\text {st }}$ edition. New Delhi, Jaypee Brothers Medical Publishers, 2006:77-81.

14. Tyagi S, Saxena R, Choudhry VP. HPLC-how necessary is it for haemoglobinopathy diagnosis in India? Indian Journal of Pathology and Microbiology 2003;46(3):390-3.

15. Patne SCU, Shukla J. Haemoglobin E. disorders in eastern Uttar Pradesh. Indian Journal Of Pathology And Microbiology 2009;52(1):110-2.

16. Shah SJ, Chauhan SC, Rathod HK, et al. A profile of cases of haemoglobinopathies at a medical college. National Journal Of Medical Research 2012;2(2):137-40.

17. Coelho G, Setna S, Simmons C. HFE mutation on iron metabolism in beta thalassemia. Ind Jr Child Health 1958;7:378.

18. Karthika M, Devi KG, Rymbui DB, et al. Prevalence of haemoglobinopathies in Manipur. Journal of Dental and Medical Science 2015;14(8):17-20.

19. Dash S, Chhanchimi L, Chhakchhuck L, et al. Screening for haemoglobinopathies and G6PD deficiency among the Mizos of Mizoram: a preliminary study. Indian J Pathol Microbiol 2005;48(1):17-8.

20. Das MK, Dey B, Roy M, et al. High prevalence of $\mathrm{HbE}$ in 3 populations of the Malda District, West Bengal, India. Hum Hered 1991;41(2):84-8.

21. Das B, Sengupta S. HbE: genotypes and fertility study on a Tibeto-Burmese population in Upper Assam, India. Ann Hum Biol 2008;35(4):422-31.

22. Singh MR, Singh TS. Genetic polymorphism at three loci in two populations of Manipur, India. Anthropol Anz 2008;66(2):191-8.

23. Baruah MK, Saikia M, Baruah A. Pattern of haemoglobinopathies and thalassemias in upper Assam region of north eastern India. High performance liquid chromatography studies in 9000 patients. Indian Journal of Pathology and Microbiology 2014;57(2):236-43.
24. Aggarwal S, Saluja S, Bhasin S, et al. $\mathrm{HbE}$ variantsretrospective analysis in a tertiary care centre. Journal Indian Academy of Clinical Medicine 2011;12(4):263-5.

25. Chattopadhyay K, Biswas R, Bhattacherjee S, et al. An epidemiological study on the clinic-haematological profile of patients with congenital haemolytic anaemia in a tertiary care hospital of Kolkata. Indian J Prev Soc Med 2012;43(4):372-7.

26. Krishnamurti L. Few cases of $\mathrm{HbE}$ beta thalassemia in northeast India. Under diagnosis or complete exclusion of beta thalassemia by haemoglobin E. Journal of Paediatric Haematology Oncology 2000;22(6):558-63.

27. Agarwal MB. The burden of haemoglobinopathies in India-time to wake up? Assoc Physicians India 2005;53:1017-8

28. Balgir RS. Genetic epidemiology of the three predominate abnormal haemoglobins in India. J Assoc Physicians India 1996;44(1):25-8.

29. Angastiniotis M, Modell B, Englezos P, et al. Prevention and control of haemoglobinopathies. Bull World Health Organ 1995;73(3):375-86.

30. Cao A, Rosatelli MC, Monni G, et al. Screening for thalassemia: a model of success. Obstet Gynaecol Clin N Am 2002;29(2):305-28.

31. Loukopoulous D. Haemoglobinopathies in Greece: prevention programme over the last 35 years. Indian J Med Res 2011;134(4):572-6.

32. Weatherall DJ. The challenge of haemoglobinopathies in resource poor countries. Br J Haematol 2011;154(6): 736-44. 